\title{
Why it is difficult to distinguish the Silver-Russell syndrome (SRS) and 3M syndrome in clinical practice
}

Beibei Zhang

Department of Endocrinology, Genetics, Metabolism, Beijing Children's Hospital, Capital Medical University, National Center for Children's Health, Beijing 100045, China

Chunxiu Gong ( $\nabla$ chunxiugong@sina.com )

Department of Endocrinology, Genetics, Metabolism, Beijing Children's Hospital, Capital Medical University, National Center for Children's Health, Beijing 100045 , China

\section{Research}

Keywords: Silver-Russell syndrome, 3M syndrome, NH-CSS, Phenotype

Posted Date: April 15th, 2020

DOI: https://doi.org/10.21203/rs.3.rs-22088/v1

License: @ (i) This work is licensed under a Creative Commons Attribution 4.0 International License. Read Full License 


\section{Abstract}

Background: To analyze why $3 \mathrm{M}$ syndrome can be regarded as a SRS-like syndrome by examining the patients with $3 \mathrm{M}$ syndrome and research the connection between $3 \mathrm{M}$ syndrome and SRS.

Methods: The term "3M syndrome" was retrieved by Web of Science and the 3M patients were screened by NH-CSS to determine whether it was consist with the diagnosis of clinical SRS, and to analyze the relationship between the two diseases by exploring literature.

Results: $\triangle$ Among patients with 3M syndrome, 60/70 (83\%) were in accordance with clinical SRS, and the coincidence rates of CUL7, OBSL $1, C C D C 8$ gene

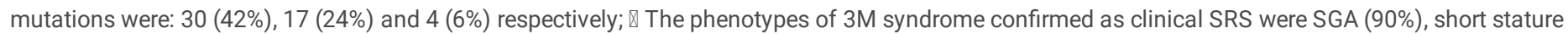
(100\%), forehead protruding (100\%), relative macrocephaly (100\%), feeding difficulties/low BMI (33\%), body asymmetry (0); $\otimes$ Skeletal abnormalities and pathogenesis were previously considered as the key points of differentiation also were overlaps between two diseases; $₫$ Symptomatic treatment and GHtreatment were carried out.

Conclusions: $₫$. There isn't reliable clinical points to distinguish the two diseases, especially for the patients with CUL 7 mutations whose imaging is not typical, which need to rely on genetic detection; $₫$. Literature research points out the two diseases may have the same pathogenic pathway; $\Downarrow$. Both of diseases were treated symptomatically and used GH to improve height; $₫$. 3M syndrome diagnosed "clinical SRS" can incorporate into SRS to facilitate clinical classification and management.

\section{Background}

Silver-Russell syndrome (SRS, OMIM\#180860) is a rare dwarf disease characterized by intrauterine and postnatal growth retardation, but it is separated from other SGA because of body asymmetry, forehead protruding, relative macrocephaly and specific facial manifestations. The disease was first described by Silver in 1953 and Russell in 1954[1-2]. In addition to intrauterine growth restriction, SGA, postnatal growth retardation, short stature, typical facial abnormalities (triangular-shaped face, forehead protruding, relative macrocephaly, etc.) and asymmetries (face, limbs), there are other symptoms including low BMI, feeding difficulties, irregular dentition, fifth finger clinodactyly, prominent heels, etc [3-4]. The etiology study found that $30 \%-60 \%$ patients with molecular abnormalities of chromosome $11 \mathrm{p} 15.5, \leq 10 \%$ had upd(7)mat, and others without clear etiology [5]. Other gene and chromosome abnormalities reported in the literatures can be found in SRS [6].

Scholars had summarized several diagnostic criteria for Silver Russell syndrome, until 2015, Azzi et al. proposed the criteria which was recommended by international consensus in 2017 due to its relatively high sensitivity and specificity [4]. TÜmer et al. reviewed and summarized the NH-CSS and classified the disease as SRS, clinical SRS, molecular SRS and non-SRS [7] (see Supplement table A.1).

In 1975, more than 20 years after the proposal of SRS, a group of SGAs with skeletal malformation as the main manifestation was named 3M syndrome, which originated from the initials of three experts (Miller, McKusick, Malvaux). The mainly phenotypes of the disease were low birth weight, serious short stature, narrow facies, clinodactyly and normal intelligence [8]. 3M syndrome is a rare autosomal recessive disease, which can be divided into three subtypes according to gene mutations: 3M1 (OMIM\#273750) is related to CUL7gene variation on chromosome 6q21.1, 3M2 (OMIM\#612921) is related to OBSL1 gene variation on chromosome 2q35, 3M3 (OMIM\#614205) is related to CCDC8 gene variation on chromosome $19 \mathrm{q} 13.32$, with incidence rate of $65 \%$, 30\% and 5\%, respectively [9]. Skeletal abnormality is more specific in 3M syndrome, so it is grouped as "Slender bone dysplasia group" in 2015 . The main features are long, slender tubular bones, reduced anteroposterior diameter of the vertebral bodies and delayed bone age [10].

Up to now, due to the small number of reports on $3 \mathrm{M}$ syndrome, there is no exact diagnostic standard. It is mainly diagnosed by comprehensive analysis of clinical manifestations, imageology examination and genetic testing. Because the body asymmetry is not necessary for SRS, 3M syndrome patients are often misdiagnosed as SRS, and it can only be corrected when get the genetic results, such as our reported patients [11]. Some scholars have proposed it is difficult to discriminate $3 \mathrm{M}$ syndrome from SRS. Based on this point of view, we searched patients with $3 \mathrm{M}$ syndrome, evaluated them with the diagnostic criteria of SRS, and found the relationship between the two diseases through literature.

\section{Results}

We obtained 241 pieces of information after using the Web of Science to search for the term "3M syndrome". After evaluating the content of the literature, 17 articles were included and 72 cases of $3 \mathrm{M}$ syndrome with detailed description were obtained. And then further study on the two diseases through literature.

1. Among 72 patients, 32 cases (44\%) had CUL7 gene variants, 22 (31\%) had OBSL 1 gene variants and 8 (11\%) had CCDC 8 gene variants, while, 10 patients (14\%) without gene detection were reported in the literature (see Table 1). Reports of 3M syndrome was common in the Middle East (51/72, 71\%). Most of parents were married to close relatives, gave birth at full-term production without abnormally during pregnancy.

2. The clinical manifestation of the group included SGA, postnatal growth retardation, forehead protruding, relative macrocephaly and feeding difficulties/ low BMI, according to the NH-CSS, they could be diagnosed as clinical SRS. Among 72 patients, 60 cases met the diagnostic criteria (83\%), of which the coincidence rate was 30 cases (42\%) with CUL7 gene mutation, 94\% (30/32); 17 cases (28\%) with OBSL1 gene mutation, $77 \%$ (17/22); 4 cases with CCDC8 gene mutation, $50 \%$ (4/8); and 9 other patients (15\%) with undefined genes could be diagnosed as "clinical SRS" (see Figure 1). Of the 60 diagnosed patients, 54 were SGA (90\%), 60 were all born with postnatal growth retardation (100\%), forehead protruding (100\%), and relative macrocephaly (100\%), 16 had difficulty feeding /low BMI (27\%), and none of them presented body asymmetry (0) (see Table 2).

3. Differences in identification points. Skeletal abnormalities reported in previous $3 \mathrm{M}$ syndrome such as scoliosis, tall vertebral bodies, fifth finger clinodactyly, and prominent heels are also reported in SRS patients with 11p15 ICR1 LOM; while, the clinical manifestations of SRS such as forehead

Page $2 / 10$ 
protruding and relative macrocephaly are also present in patients with 3M syndrome. 1. In 2009, Bruce et al. [12] addressed that patients with severe hypomethylation of $\mathrm{H} 19$ in the 11p15 ICR1 region could also exhibit skeletal abnormalities, such as high lumbar vertebrae, lumbar hypomobility, and distinct hand and foot anomalies. 2. In 2018, Tümer et al. [7] pointed out, although the two symptoms of forehead protruding and relative macrocephaly are relatively subjective in diagnosis, they are the key points in distinguishing SRS from other SGAs. In the diagnostic criteria of SRS, forehead protruding and relative macrocephaly were needed when patients only presented four of six indicators and negative genetic testing, while the patients with $3 \mathrm{M}$ syndrome also showed the two phenotypes. 3 . There are other common phenotypes can present in the two disease, such as delayed bone age, male sexual dysfunction (like hypospadias, spermatogenesis dysfunction) and normal intelligence. 4. In 2011, Akawi et al. [13] pointed out that the autosomal recessive SRS could be classified into $3 \mathrm{M}$ syndrome. Therefore, it is difficult to distinguish the two diseases.

4. Study on the pathogenesis in literature.

The causes of $3 \mathrm{M}$ syndrome are CUL7, OBSL 1, CCDC8 mutations. For the CUL7 protein, which is the major member of CRL7 (including CUL7, Fbw8, SK1, ROC1), targets IRS1 for Mtorc1/S6K1-dependent degradation [14]. When knock out Cul7 in mouse embryonic fibroblasts, can decrease the IRS1 degradation and increase Akt and Mapk activation and led to poor cell growth and cellular senescence [15]. Both of OBSL1 and CCDC8 can act with CUL7 to form a 3M complex to maintain normal cell growth [16]. Chrom11p15-ICR1 LOM and UPD(7)mat are the classical causes for SRS. 11p15-ICR1 LOM can lead to decrease IGF2 expression and increase H19 transcriptional level, which influence the IGF1R pathway to lead to abnormal cell growth [17]. While GRB10, a candidate gene on UPD(7)mat not only interacts with IGF1/IGF1R, but interacts with IRS1 (See the Figure 3). From the results and figures, we thought that both of them are maybe in the same pathway for pathogenesis. See the supplement table A.3 and Figure 2-3.

\section{Treatment for the two diseases.}

Both of them are symptomatic treatment and GH to improve height, especially SRS is the only SGA-syndrome which used GH to improve height certified by international consensus in 2017. The $3 \mathrm{M}$ syndrome is also treated with $\mathrm{GH}$, but the effect is controversial due to the small number of cases. Detailed information can be found in supplement table A.2.

\section{Discussion}

SRS is an earlier and relatively common clinically identifiable syndrome in SGA, subsequent clinical application with gene detection technology; more syndromes are known, including $3 \mathrm{M}$ syndrome. $3 \mathrm{M}$ syndrome is relatively rare, and we find that it is difficult to identify from SRS through clinical manifestations in our clinical experience, but requires genetic testing to determine. The problem has been noted by scholars for a long time. When SRS was studied using NH-CSS, it was found that the diagnostic rate of SRS was $76.7 \%$. In this paper, we used the NH-CSS criteria to study the clinical coincidence rate of $3 \mathrm{M}$ syndrome, and found that $83 \%$ of patients with $3 \mathrm{M}$ syndrome can be diagnosed as clinical SRS, which is even higher than the SRS. NH-CSS is recently recognized as the standard with optimized sensitivity and specificity; it still showed difficult to identify the two diseases in clinical practice.

We believe that the high clinical similarity of the two diseases is mainly caused by $\otimes$ The diagnosis criteria of the 2 diseases have the same main clinical manifestation, such as "Height/ weight at birth and after birth less than the same age, feeding difficulties, low BMI, typical face deformities (micrognathia, triangular-shaped face, forehead protruding, relatively enlarged head circumference)", 凶Other minor criteria share same symptoms, such as prominent heel, clinodactyly, male sexual dysfunction was showed in two diseases [18], and the skeletal deformity of 3M syndrome was not completely absent in SRS. Therefore, it is not easy to distinguish SRS or $3 \mathrm{M}$ syndrome for children without body asymmetry. खGenetic detection is currently a differential method. While if they are not the classical pathogenic genes or gene detection negative, the diagnosis is still a challenge. At that time, we have to make clinical diagnosis. We recommended that $3 \mathrm{M}$ syndrome can be further differentiated when SRS is diagnosed clinically.

Since we propose that clinical diagnosis is basic and necessary, we explore why these syndromes are so similar? In addition to the same clinical manifestations described above, we also analyzed the two diseases from the following aspects. The results of clinical data have already fully demonstrated the homology of the two diseases. In genetic research, we found that many patients with $3 \mathrm{M}$ syndrome were born in Turkey and Arabia, where the marriage rate of close relatives was relatively high. It could explain that the heredity mode of 3M syndrome was autosomal recessive of $C U L 7, O B S L 1$, and $C C D C 8$ gene mutations. Whereas patients with SRS had different inheritance, including autosomal recessive, autosomal dominant, $\mathrm{X}$ chromosome dominant and others [19]. It has been found that 11p15 ICR1 LOM and UPD(7)mat are the most common epigenetic abnormalities and can diagnose about 60-70\% of SRS patients. Although they are different pathogenic factors, both of them affect the expression of IGF2, which lead to intrauterine growth restriction [17,20]. On the other hand, both of them have an effect on GH-IGF1 axis. We conclude that from above researches, the two diseases may have the same pathway root.

Although the pathogenic mechanism is homologous, there are some phenotypic differences between the two syndromes. Because of intrauterine growth restriction, SGA, and postnatal growth retardation, the adult lifetime height of the two diseases is lower than those of normal peers. While the final height in $3 \mathrm{M}$ syndrome patients is lower than of SRS [21], we explained that above three gene changes in 3M syndrome influence the expression of three proteins, therefore affect the normal growth cycles of cells, but the epigenetic abnormality of SRS does not change the gene sequence, it affects the expression of growth-related proteins.

For the clinical management, the two diseases mainly adopt symptomatic treatment and regular follow-up [5,22]. At present, the treatment of height is still the most concern of the two diseases. When reviewed the literatures, we found that the level of IGF1 and GH in both diseases were generally normal, they were a lack of catch-up growth after birth. In the case report, it was found that both diseases were treated with GH which was suitable for SGA. The guideline pointed out SRS was the only syndrome to be included in the clinical trials of GH in short children born SGA and an indication for growth-promoting treatment under the SGA registered. The longitudinal study of Smeets et al. [23] showed that the therapeutic effect of GH on patient with SRS was parallel to patients with nonSRS SGA. After treatment, the patients with SRS had an average increase of 1.3SD. Due to the patients with 3M syndrome were born SGA, GH was also the main treatment in this group. Although the treatment effect of $3 \mathrm{M}$ syndrome is inferior to SRS, we consider the possibility of fewer cases, less clinical

Page $3 / 10$ 
experience, and insufficient treatment. However, $\mathrm{GH}$ can still improve a certain degree of height from the treatment reported in the case of $3 \mathrm{M}$ syndrome [2426].

\section{Conclusion}

1. From the clinical manifestations, most patients with 3M syndrome meet the diagnostic criteria of NH-CSS and can be diagnosed as clinical SRS. Skeletal abnormalities specific to $3 \mathrm{M}$ syndrome can be found in SRS sometimes, while, body asymmetry is not presented in all patients with SRS. So, it is not always clinically distinguishable between SRS and 3M syndrome.

2. From the genetic information, the genetic patterns of the two diseases are different, but their pathogenic causes can lead to the down regulation of IGF2 expression. So, we consider both of two diseases may share a same branch in the pathogenic pathway.

3. From the clinical treatment, both of them are treated symptomatically, and the problem of height in two diseases is also treated with $\mathrm{GH}$.

In summary, we find that patients with 3M syndrome have a large overlap with SRS in clinical manifestations, pathogenic factors and treatment. In order to facilitate clinical diagnosis and management, we consider that $3 \mathrm{M}$ syndrome can be classified into SRS, and use the $\mathrm{NH}-\mathrm{CSS}$ standard to diagnose the patients with special facial deformities and skeletal dysfunction, and conduct unified management. This has certain advantage for clinicians, because it can reduce clinical misdiagnosis. Although the diseases are easy to be confused, we suggest that the clinical diagnosis can be carried out together, but gene detection and identification are also very important, especially for genetic counseling.

Although our view is biased towards that 3M syndrome can be included in SRS for unified management and treatment, some problems remain unresolved. 1. In our summary, we found that the same protein test results as 11p15 ICR1 LOM were found in cell experiments of 3M syndrome, but were not verified in vivo. Further research is needed to confirm whether the results of protein testing is due to the causative gene of $3 \mathrm{M}$ syndrome is an upstream regulatory gene of $\mathrm{H} 19$ or IGF2, or a certain interaction between these proteins. 2. The management of $3 \mathrm{M}$ syndrome is still not standardized. Due to the small number of cases, individual data cannot represent the general rule, so further research is needed for treatment.

\section{Materials And Methods}

1. Search for the term "3M syndrome" in Web of Science, and collect the clinical cases reported in the literature;

2. Inclusion criteria: Cases with detailed description in the literature were studied. Exclusion criteria: Due to the data at birth or after birth is not clear, and the phenotype after adulthood has been blurred, therefore, we exclude the literature of children and adults who lack relevant data.

3. The patients with 3M syndrome were screened by the criteria of NH-CSS, and diagnosed as clinical SRS if the clinical conditions were met.

4. To review the clinical manifestations and pathogenesis of the two diseases, analyze the similarities and differences of clinical phenotypes and the relationship between the pathogenesis.

5. To find the protein interaction through the STRING website (https://string-db.org/).

\section{Declarations}

Ethics approval and consent to participate: No applicable.

Consent for publication: No applicable.

Availability of data and materials: No applicable.

Authors' contributions: The authors declare that they have no competing interests.

Funding: This work was supported by the National Natural Science Foundation of China (81670713), National Key Research and Development Program of China (2016YFC0901505), and Beijing Municipal Administration of Hospital Clinical Medicine Development (ZYLX201821).

Contribution statement. Study concept and design: CXG. Acquisition, analysis, or interpretation: CXG and BBZ. Drafting of the manuscript: BBZ. Critical revision of the manuscript for important intellectual content: CXG and BBZ. Obtained funding: CXG. All authors have read and approved the final manuscript.

Acknowledgements: We thank all the participants for their efforts, will and commitment to be involved in the study.

\section{References}

1. Silver HK, Kiyasu W, George J, Deamer WC. Syndrome of congenital hemihypertrophy, shortness of stature, and elevated urinary gonadotropins. Pediatrics. 1953;12(4):368-376.

2. Russell A. A syndrome of intra-uterine dwarfism recognizable at birth with cranio-facial dysostosis, disproportionately short arms, and other anomalies (5 examples). Proc R Soc Med. 1954;47(12):1040-1044.

3. Zhu MQ, Gong CX., Wu D, Huang SY, Cao BY. Analysis of clinical and genetic characteristics of 20 cases of children with Silver Russell syndrome. Zhonghua Er Ke Za Zhi. 2013;51(3):216-220. https://doi.org/10.3760/cma.j.issn.0578-1310.2013.03.013

4. Azzi S, Salem J, Thibaud N, Chantot-Bastaraud S, Lieber E, Netchine I, et al. A prospective validating a clinical scoring system and demonstrating phenotypical-genotypical correlations in Silver-Russell syndrome. J Med Genet. 2015;52(7):446-453. https://doi.org/10.1136/jmedgenet-2014-102979

Page $4 / 10$ 
5. Wakeling EL, Brioude F, Lokulo-Sodipe O, O'Connell SM, Salem J, Bliek J, et al. Diagnosis and management of Silver-Russell syndrome: first international consensus statement. Nat Rev Endocrinol. 2017;13(2):105-124. https://doi.org/10.1038/nrendo.2016.138

6. Spiteri BS, Stafrace Y, Calleja-Agius J. Silver-Russell Syndrome: A Review. Neonatal Netw. 2017, 36(4):206-212. https://doi.org/10.1891/07300832.36.4.206

7. TÜmer Z, López-Hernández JA, Netchine I, Elbracht M, Grønskov K, Gede LB, et al. Structural and sequence variants in patients with Silver-Russell syndrome or similar features-Curation of a disease database. Hum Mutat. 2018;39(3):345-364. https://doi.org/10.1002/humu.23382

8. Miller JD, McKusick VA, Malvaux P, Temtamy S, Salinas C. The 3-M syndrome: a heritable low birthweight dwarfism. Birth Defects Orig Artic Ser. 1975;11(5):39-47.

9. Simsek-Kiper PO, Taskiran E, Kosukcu C, Arslan UE, Cormier-Daire V, Gonc N, et al. Further expanding the mutational spectrum and investigation of genotype-phenotype correlation in 3M syndrome. Am J Med Genet A. 2019;179(7):1157-1172. https://doi.org/10.1002/ajmg.a.61154.

10. Bonafe L, Cormier-Daire V, Hall C, Lachman R, Mortier G, Mundlos S, et al. Nosology and classification of genetic skeletal disorders: 2015 revision. Am J Med Genet A. 2015;167A(12):2869-92. https://doi.org/10.1002/ajmg.a.37365.

11. Hu X, Li H, Gui B, Xu Y, Wang J, Li N, et al. Prenatal and early diagnosis of Chinese 3-M syndrome patients with novel pathogenic variants. Clin Chim Acta. 2017;474:159-164. https://doi.org/10.1016/j.cca.2017.09.022.

12. Burce S, Hannula-Jouppi K, Peltonen J, Kere J, Lipsanen-Nyman M. Clinically distinct epigenetic subgroups in Silver-Russell syndrome: the degree of H19 hypomethylation associates with phenotype severity and genital and skeletal anomalies. J Clin Endocrinol Metab. 2009;94(2):579-587. https://doi.org/10.1210/jc.2008-1805.

13. Akawi NA, Ail BR, Hamamy H, Al-Hadidy A, Al-Gazali L. Is autosomal recessive Silver-Russel syndrome a separate entity or is it part of the 3-M syndrome spectrum? Am J Med Genet A. 2011;155A(6):1236-1245. https://doi.org/10.1002/ajmg.a.34009.

14. Xu X, Keshwani M, Meyer K, Sarikas A, Taylor S, Pan ZQ. Identification of the degradation determinants of insulin receptor substrate 1 for signaling cullinRING E3 ubiquitin ligase 7-mediated ubiquitination. J Biol Chem. 2012;287(48):40758-40766. https://doi.org/10.1074/jbc.M112.405209

15. Hanson D, Murray PG, Coulson T, Sud A, Omokanye A, Stratta E, et al. Mutations in CUL7, OBSL1 and CCDC8 in 3-M syndrome lead to disordered growth factor signaling. J Mol Endocrinol. 2012;49(3):267-275. https://doi.org/10.1530/JME-12-0034.

16. Yan J, Yan F, Li Z, Sinnott B, Cappell KM, Yu Y, et al. The 3M complex maintains microtubule and genome integrity. Mol Cell. 2014;54(5):791-804. https://doi.org/10.1016/j.molcel.2014.03.047.

17. Gicquel C, Rossignol S, Cabrol S, Houang M, Steunou V, Barbu V, et al. Epimutation of the telomeric imprinting center region on chromosome $11 \mathrm{p} 15$ in Silver-Russell syndrome. Nat Genet. 2005:37(9):1003-1007. https://doi.org/10.1038/ng1629.

18. Huang SY, Gong CX, Zhao Y, Wu D, Cao B. A clinical study of 35 cases of Silver-Russell syndrome. Chinese Journal of Endocrinology and Metabolism. 2014;30(2):119-122. https://doi.org/10.3760/cma.j.issn.1000-6699.2014.02.008.

19. Duncan PA, Hall JG, Shapiro LR, Vibert BK. Three-generation dominant transmission of the Sliver-Russell syndrome. Am J Med Genet. 1990;35(2):245250. https://doi.org/10.1002/ajmg.1320350220.

20. Murray PG, Hanson D, Coulson T, Stevens A, Whatmore A, Poole R L, et al. 3-M syndrome: a growth disorder associated with IGF2 silencing. Endocr Connect. 2013;2(4):225-235 https://doi.org/10.1530/EC-13-0065.

21. Clayton PE, Hanson D, Mageem L, Murray PG, Sauunders E, Abu-Amero SN, et al. Exploring the spectrum of 3-M syndrome, a primordial short stature disorder of disrupted ubiquitination. Clin Endocrinol (Oxf). 2012;77(3):335-342. https://doi.org/10.1111/j.1365-2265.2012.04428.x.

22. Irving M, Holder-Espinasse M. Three M syndrome, in: Adam, M.P., Ardinger, H.H., Pagon, R.A., Wallace, S.E., Bean, L.J.H., Stephens, K., Amemiya, A. (Eds.), GeneReviews. University of Washington. 2019;1993-2019 p.

23. Smeets CC, Renes JS, van der Steen M, Hokken-Koelega AC. Metabolic Health and Long-Term Safety of Growth Hormone Treatment in Sliver-Russell Sydrome. J Clin Endocrinol Metab. 2017;102(3):983-991. https://doi.org/10.1210/jc.2016-3388.

24. Meazza C, Lausch E, Pagani S, Bozzola E, Calcaterra V, Superti-Furga A, et al. 3-M syndrome associated with growth hormone deficiency: 18 year followup of a patient. Ital J Pediatr. 2013;39:21. https://doi.org/10.1186/1824-7288-39-21.

25. Takatani T, Shiohama T, Takatani R, Shimojo N, et al. A novel CUL7 mutation in a Japanese patient with 3M syndrome. Hum Genome Var. $2018 ; 5: 30$. https://doi.org/10.1038/s41439-018-0029-3.

26. Keskin M, Muratoǵlu Sahin N, Kurnaz E, Kurnaz E, Bayramoǵlu E, Savas Erdeve S, et al. A Rare Cause of Short Stature: 3M Syndrome in a Patients with Novel Mutation in OBSL1 Gene. J Clin Res Pediatr Endocrinol. 2017;9(1):91-94. https://doi.org/10.4274/jcrpe.3238.

27. HabibUllah H, Al-Baradie R, Bashir S. 3-M Syndrome: A Local Case Report. Am J Case Rep. 2019;20:36-38. https://doi.org/10.12659/AJCR.912736.

28. Lugli L, Bertucci E, Mazza V, Elmakky A, Ferrari F, Neuhaus C, et al. Pre-and post-natal growth in two sisters with 3-M syndrome. Eur J Med Genet. 2016;59(4):232-236. https://doi.org/10.1016/j.ejmg.2016.01.009.

29. Liao L, Gan HW, Hwa V, Dattani M, Dauber A. Two Siblings with a Mutation in CCDC8 Presenting with Mild Short Stature: A Case of 3-M Syndrome. Horm Res Paediatr. 2017;88(5):364-370. https://doi.org/10.1159/000477907.

30. Güven A, Cebeci AN. 3M syndrome: a report of four cases in two families. J Clin Res Pediatr Endocrinol. 2011;3(3):154-159. https://doi.org/10.4274/jcrpe.v3i3.30.

31. Dauber A, Stoler J, Hechter E, Safer J, Hirschhorn JN. Whole exome sequencing reveals a novel mutation in CUL7 in a patient with a undiagnosed growth disorder. J Pediatr. 2013;162(1):202-204. https://doi.org/10.1016/j.jpeds.2017.07.055.

32. Hanson D, Murray PG, O'Sullivan J, Urquhart J, Daly S, Bhaskar SS, et al. Exome sequencing identifies CCDC8 mutations in 3-M syndrome, suggesting that CCDC8 contributes in a pathway with CUL7 and OBSL1 to control human growth. Am J Hum Genet. 2011;89(1):148-153.

Page 5/10 
https://doi.org/10.1016/j.ajhg.2011.05.028.

33. Sasaki K, Okamoto N, Kosaki K, Yorifuji T, Shimokawa O, Mishima H, et al. Maternal uniparental isodisomy and heterodisomy on chromosome 6 encompassing a CUL7 gene mutation causing 3M syndrome. Clin Genet. 2011;80(5):478-483. https://doi.org/10.1111/j.1399-0004.2010.01599.x.

34. van der Wal G, Otten BJ, Brunner HG, van der Burgt I. 3-M syndrome: description of six new patients with review of the literature. Clin Dysmorphol. 2001;10(4):241-252. https://doi.org/ 10.1097/00019605-200110000-00002.

35. Deeb A, Afandi O, Attia S, Fatih AE. 3-M syndrome: a novel CUL7 mutation associated with respiratory distress and a good response to GH therapy. Endocrinol Diabetes Metab Case Rep. 2015;2015:150012. https://doi.org/10.1530/EDM-15-0012.

36. Demir K, Altincik A, Böber E. Severe short stature due to 3-M syndrome with a novel OBSL1 gene mutation. J Pediatr Endocrinol Metab. 2013;26(1-2):147150. https://doi.org/10.1515/jpem-2012-0239.

37. Al-Dosari MS, Al-Shammari M, Shaheen R, Faqeih E, Alghofely MA, Boukai A, et al. 3M syndrome: an easily recognizable yet underdiagnosed cause of proportionate short stature. J pediatr. 2012;161(1):139-145. https://doi.org/10.1016/j.jpeds.2011.12.051.

38. Calyton PE, Cianfarani S, Czernichow P, Johannsson G, Rapaport R, Rogol A, et al. Management of the child born small for gestational age through to adulthood: a consensus statement of the International Societies of Pediatric Endocrinology and the Growth Hormone Research Society. J Clin Endocrinol Metab. 2007;92(3):804-810. https://doi.org/10.1210/jc.2006-2017.

\section{Tables}

Table 1. NH-CSS criteria screen 3M syndrome for clinical SRS

\begin{tabular}{|c|c|c|c|c|c|c|c|c|c|c|c|c|c|c|c|c|c|c|c|c|c|c|c|c|c|c|c|c|}
\hline \multirow{3}{*}{$\begin{array}{c}\begin{array}{c}\text { Criteria } \\
\text { Patients }\end{array} \\
\text { Genotype } \\
\text { Gestation } \\
\text { (Weeks) }\end{array}$} & \multicolumn{18}{|c|}{ Simsek-Kiper [9] } & \multirow{4}{*}{$\begin{array}{c}\begin{array}{c}\text { Habibullah } \\
{[27]}\end{array} \\
\text { CUL7mutation } \\
37 \\
19\end{array}$} & \multirow{4}{*}{$\begin{array}{c}\text { Meazza }{ }^{[24]} \\
\text { CUL7 mutation } \\
42 \\
20\end{array}$} & \multirow{4}{*}{$\begin{array}{c}\begin{array}{c}\text { Takatani } \\
{[25]}\end{array} \\
\text { CUL7mutation } \\
41 \\
21\end{array}$} & \multirow{4}{*}{\begin{tabular}{|c|} 
Keskin ${ }^{[26]}$ \\
OBSL1 mutation \\
39 \\
22 \\
\end{tabular}} & \multirow{2}{*}{\multicolumn{2}{|c|}{\begin{tabular}{|l|} 
Lugli ${ }^{[28]}$ \\
CUL7mutation \\
\end{tabular}}} & \multirow{2}{*}{\multicolumn{3}{|c|}{$\begin{array}{c}\mathrm{Hu}{ }^{[11]} \\
\text { CUL7mutation } \\
\end{array}$}} & \multirow{4}{*}{ 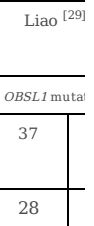 } \\
\hline & & & & & CUL $7 \mathrm{n}$ & utation & & & & & & & & OBSL1: & nutation & & & & & & & & & & & & & \\
\hline & \multicolumn{18}{|c|}{$\mathrm{NM}^{\dagger}$} & & & & & \multicolumn{2}{|c|}{$\mathrm{NM}^{\dagger}$} & \multicolumn{3}{|c|}{$\mathrm{NM}^{\dagger}$} & \\
\hline Number & 1 & 2 & 3 & 4 & 5 & 6 & 7 & 8 & 9 & 10 & 11 & 12 & 13 & 14 & 15 & 16 & 17 & 18 & & & & & 23 & 24 & 25 & 26 & 27 & \\
\hline SGA & + & + & + & + & + & + & + & + & + & + & - & + & + & + & + & + & - & + & + & + & + & + & + & + & + & + & + & - \\
\hline $\begin{array}{c}\text { Postnatal } \\
\text { growth } \\
\text { restriction }\end{array}$ & + & + & + & + & + & + & + & + & + & + & + & + & + & + & + & + & + & + & + & + & + & + & + & + & + & + & + & + \\
\hline $\begin{array}{c}\text { relative } \\
\text { macrocephaly }\end{array}$ & + & + & + & + & + & + & + & + & + & + & + & + & + & + & + & + & - & + & + & + & + & $\mathrm{NM}^{\dagger}$ & + & + & + & + & + & $\mathrm{NM}^{\dagger}$ \\
\hline $\begin{array}{l}\text { forehead } \\
\text { protruding }\end{array}$ & + & + & + & + & + & + & + & + & + & + & + & + & + & + & + & + & + & + & + & + & + & - & + & + & + & + & + & + \\
\hline $\begin{array}{c}\text { Body } \\
\text { asymmetry }\end{array}$ & - & - & - & - & - & - & - & - & - & - & - & - & - & - & - & - & - & - & - & - & - & - & - & - & - & $\mathrm{NM}^{\dagger}$ & $\mathrm{NM}^{\dagger}$ & - \\
\hline $\begin{array}{c}\text { difficulty } \\
\text { feeding } \\
\text { /BMI }-2 \text { SDS }\end{array}$ & - & - & - & - & - & + & - & - & - & - & - & & - & - & - & - & + & - & - & & - & - & - & - & - & $\mathrm{NM}^{\dagger}$ & $\mathrm{NM}^{\dagger}$ & - \\
\hline Clinical SRS & $\mathrm{Y}^{\ddagger}$ & $\mathrm{Y}^{\ddagger}$ & $\mathrm{Y}^{\ddagger}$ & $\mathrm{Y}^{\ddagger}$ & $\mathrm{Y}^{\ddagger}$ & $\mathrm{Y}^{\ddagger}$ & $\mathrm{Y}^{\ddagger}$ & $\mathrm{Y}^{\ddagger}$ & $\mathrm{Y}^{\ddagger}$ & $\mathrm{Y}^{\ddagger}$ & $\mathrm{N}^{\S}$ & $\mathrm{Y}^{\ddagger}$ & $\mathrm{Y}^{\ddagger}$ & $\mathrm{Y}^{\ddagger}$ & $\mathrm{Y}^{\ddagger}$ & $\mathrm{Y}^{\ddagger}$ & $\mathrm{N}^{\S}$ & $\mathrm{Y}^{\ddagger}$ & $\mathrm{Y}^{\ddagger}$ & $\mathrm{Y}^{\ddagger}$ & $\mathrm{Y}^{\ddagger}$ & $\mathrm{N}^{\S}$ & $\mathrm{Y}^{\ddagger}$ & $\mathrm{Y}^{\ddagger}$ & $\mathrm{Y}^{\ddagger}$ & $\mathrm{Y}^{\ddagger}$ & $\mathrm{Y}^{\ddagger}$ & $\mathrm{N}^{\S}$ \\
\hline $\begin{array}{l}\text { Confirmed } \\
\text { cases }\end{array}$ & & & & & & 10 & & & & & & & & 6) & 8 & & & & $1 / 1$ & $1 / 1$ & $1 / 1$ & $0 / 1$ & & & & $3 / 3$ & & $\frac{1 / 2}{1 / 2}$ \\
\hline Country & & & & & & & & & & rkey & & & & & & & & & $\begin{array}{r}\text { Saudi } \\
\text { Arabia }\end{array}$ & Italy & Japan & Turkey & & & & China & & Americi \\
\hline
\end{tabular}

${ }^{\dagger}$ Not Mentioned; ${ }^{\ddagger}$ Yes; §None

Table 1. Continued 


\begin{tabular}{|c|c|c|c|c|c|c|c|c|c|c|c|c|c|c|c|c|c|c|c|c|c|c|c|c|c|c|c|c|}
\hline Criteria & \multicolumn{13}{|c|}{ Akawi ${ }^{[13]}$} & Sasaki ${ }^{[33]}$ & \multirow{2}{*}{\multicolumn{6}{|c|}{ Van der Wal ${ }^{[34]}$}} & Deeb $^{[35]}$ & $\operatorname{Demir}^{[36]}$ & & & & & \multicolumn{2}{|c|}{ Al-Dosari ${ }^{33}$} \\
\hline Genotype & \multicolumn{6}{|c|}{ CUL 7mutation } & \multicolumn{7}{|c|}{ OBSL1 mutation } & CUL7mutation & & & & & & & CUL 7 mutation & OBSL 1 mutation & \multicolumn{4}{|c|}{ CUL7 mutation } & & OBSLI \\
\hline $\begin{array}{c}\text { Gestation } \\
\text { (Weeks) }\end{array}$ & \multicolumn{6}{|c|}{$\mathrm{NM}^{+}$} & \multicolumn{7}{|c|}{$\mathrm{NM}^{+}$} & 36 & \multicolumn{4}{|c|}{ Full term } & & 37 & Full term & $\mathrm{NM}^{\dagger}$ & \multicolumn{6}{|c|}{ Full term } \\
\hline Number & 41 & 42 & 43 & 44 & 45 & 46 & 47 & 48 & 49 & 50 & 51 & 52 & 53 & 54 & 55 & 56 & 57 & 58 & 59 & 60 & 61 & 62 & 63 & 64 & 65 & 66 & 67 & 68 \\
\hline SGA & $\mathrm{NM}^{\dagger}$ & $\mathrm{NM}^{\dagger}$ & $\mathrm{NM}^{\dagger}$ & + & + & + & + & $\mathrm{NM}^{\dagger}$ & $\mathrm{NM}^{\dagger}$ & $\mathrm{NM}^{\dagger}$ & $\mathrm{NM}^{\dagger}$ & + & + & + & + & + & + & + & + & + & + & + & + & + & + & + & + & + \\
\hline $\begin{array}{c}\text { relative } \\
\text { macrocephaly }\end{array}$ & + & + & + & + & - & - & + & + & + & $\mathrm{NM}^{\dagger}$ & + & + & + & + & + & + & + & - & + & + & + & + & + & + & + & + & + & + \\
\hline $\begin{array}{l}\text { forehead } \\
\text { protruding }\end{array}$ & + & + & + & + & + & + & + & + & + & + & + & + & + & + & + & + & + & - & + & + & + & + & + & + & + & + & + & + \\
\hline $\begin{array}{c}\text { difficulty } \\
\text { feeding } \\
\text { /BMI } \leq-2 S D S\end{array}$ & + & + & + & + & + & + & + & + & + & + & + & + & + & + & + & - & + & - & - & - & - & - & - & - & - & - & - & - \\
\hline Clinical SRS & $\mathrm{Y}^{\ddagger}$ & $\mathrm{Y}^{\ddagger}$ & $\mathrm{Y}^{\ddagger}$ & $\mathrm{Y}^{\ddagger}$ & $\mathrm{N}^{\S}$ & $\mathrm{N}^{\S}$ & $\mathrm{Y}^{\ddagger}$ & $\mathrm{Y}^{\ddagger}$ & $\mathrm{Y}^{\ddagger}$ & $\mathrm{N}^{\S}$ & $\mathrm{Y}^{\ddagger}$ & $\mathrm{Y}^{\ddagger}$ & $\mathrm{Y}^{\ddagger}$ & $\mathrm{Y}^{\ddagger}$ & $\mathrm{Y}^{\ddagger}$ & $\mathrm{Y}^{\ddagger}$ & $\mathrm{Y}^{\ddagger}$ & $\mathrm{N}^{\S}$ & $\mathrm{Y}^{\ddagger}$ & $\mathrm{Y}^{\ddagger}$ & $\mathrm{Y}^{\ddagger}$ & $\mathrm{Y}^{\ddagger}$ & $\mathrm{Y}^{\ddagger}$ & $\mathrm{Y}^{\ddagger}$ & $\mathrm{Y}^{\ddagger}$ & $\mathrm{Y}^{\ddagger}$ & $\mathrm{Y}^{\ddagger}$ & $\mathrm{Y}^{\ddagger}$ \\
\hline $\begin{array}{c}\text { Confirmed } \\
\text { cases }\end{array}$ & & & $4 / 6$ & & & & & & & $6 / 7$ & & & & $1 / 1$ & & & & & & & $1 / 1$ & $1 / 1$ & & & & & & $/ 10$ \\
\hline Country & & & & & & & Arab & & & & & & & Japan & & & Nethe & lands & & & Arab & Turkey & & & & & Saud & Arabi \\
\hline
\end{tabular}

${ }^{\dagger}$ Not Mentioned; ${ }^{\ddagger}$ Yes; §None

Table 2. Proportion of NH-CSS scoring items in patients with $3 \mathrm{M}$ syndrome

\begin{tabular}{|c|c|c|c|c|c|c|c|}
\hline \multirow[t]{3}{*}{ NH-CSS } & \multicolumn{7}{|c|}{72 cases with $3 \mathrm{M}$ syndrome } \\
\hline & \multicolumn{3}{|c|}{60 of clinical SRS } & \multicolumn{3}{|c|}{12 of non-SRS } & \multirow[t]{2}{*}{ Total positives } \\
\hline & Positive & $\mathrm{NM}^{\dagger}$ & Negative & Positive & $\mathrm{NM}^{\dagger}$ & Negative & \\
\hline SGA & $54 \square 90 \% \square$ & $6 \square 10 \%$ & 0 & $8 \square 67 \% \square$ & $108 \%[$ & $3025 \%[$ & $62 \square 86 \% \square$ \\
\hline Postnatal growth restriction & $60 \square 100 \%]$ & 0 & 0 & $12 \square 100 \% \square$ & 0 & 0 & $72 \square 100 \%]$ \\
\hline relative macrocephaly & $60 \square 100 \%]$ & 0 & 0 & $2 \square 17 \% \square$ & $6 \square 50 \%$ & $4 \llbracket 33 \% \square$ & $62086 \% \square$ \\
\hline forehead protruding & $60 \square 100 \%$ & 0 & 0 & $9 \square 75 \%$ & 0 & $3025 \%$ & $69 \square 96 \% \square$ \\
\hline Body asymmetry & 0 & $2 \square 3 \% \square$ & $58097 \% \square$ & 0 & 0 & $\begin{array}{l}12 \square 100 \% \square \\
\end{array}$ & 0 \\
\hline difficulty feeding / BMI $\leq 2 S D S$ & $16 \square 27 \% \square$ & $203 \% \square$ & $42 \square 70 \% \square$ & $4033 \% \square$ & 0 & $8 \square 67 \% \square$ & $20 \square 28 \% \square$ \\
\hline
\end{tabular}

${ }^{\dagger}$ Not Mentioned

Figures 


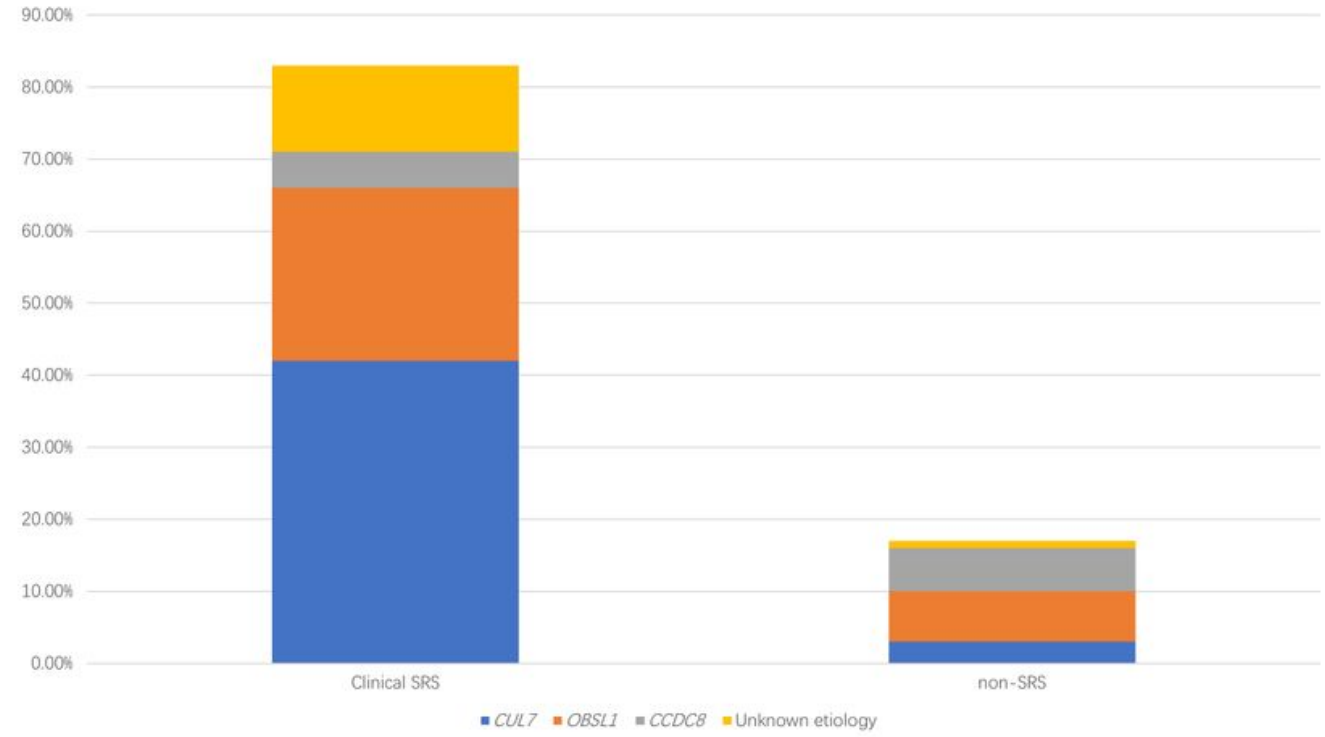

Figure 1

[No legend]

Page $8 / 10$ 


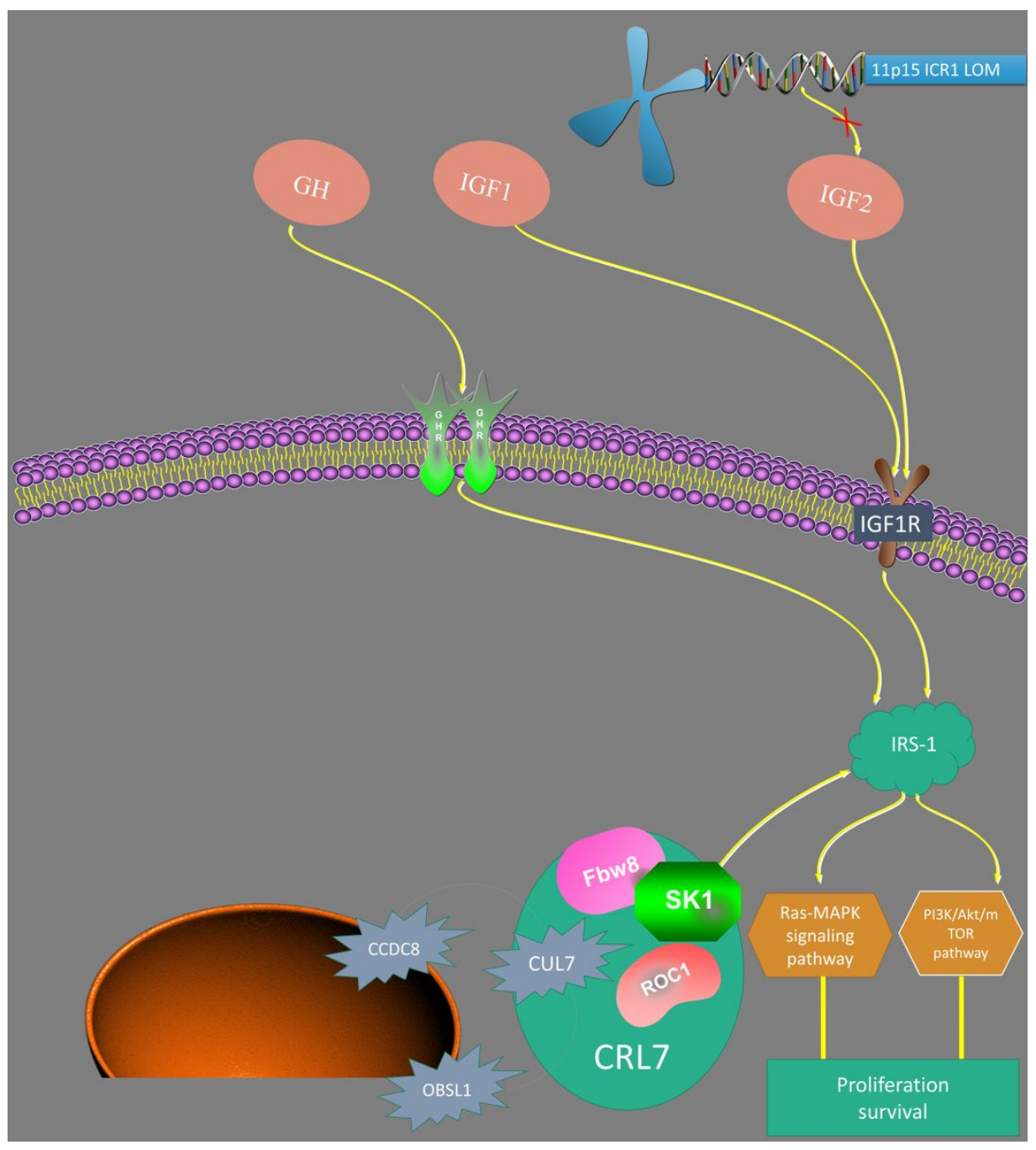

Figure 2

[No legend] 


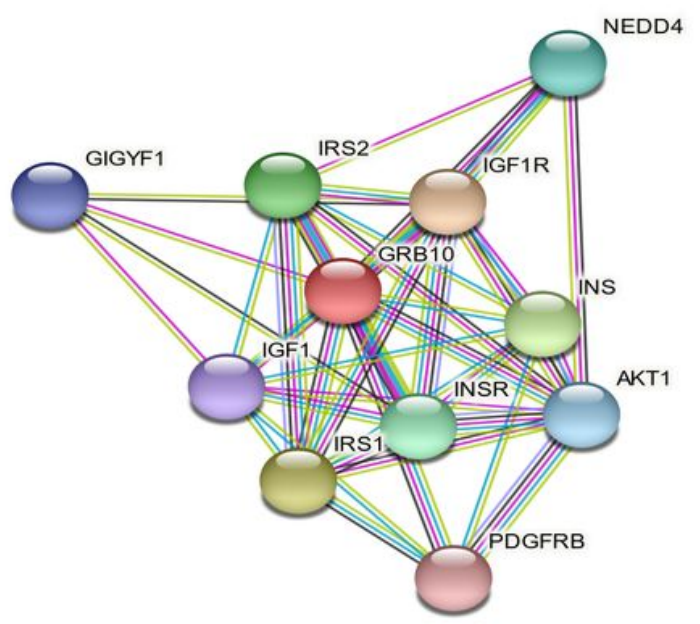

Figure 3

[No legend]

\section{Supplementary Files}

This is a list of supplementary files associated with this preprint. Click to download.

- Additionalfile1.pdf 